\title{
The European Union as a Security Actor: Moving Beyond the Second Pillar
}

\author{
Kamil Zwolski
}

\begin{abstract}
It is suggested in this article that there is a discrepancy between, on the one hand, literature that focuses on the European Union (EU) as a security actor and, on the other, contemporary security studies literature. This difference concerns the fact that the literature on the EU as a security actor treats security in a narrower sense than how it is approached in the literature on security studies. Over the past few decades, security studies literature has begun to fully acknowledge that the concept of security has broadened beyond traditional 'hard' security concerns and can encompass many different issues, for example the security implications of climate change. However, the literature on the EU as a security actor very often associates security only with the second pillar of the EU's organisational structure; in particular the intergovernmental cooperation embodied by the Common Foreign and Security Policy (CFSP) and the European Security and Defence Policy (ESDP). The main purpose of this article is to utilise the broader security studies approach to security as a means to expand the understanding of security in the context of the EU's performance on the international stage. This is important because it allows the Union's 'actorness' in the field of security to be examined in a more holistic manner.
\end{abstract}

A REVIEW OF THE LITERATURE ON THE EU AS A SECURITY ACTOR REVEALS THE tendency to approach 'security' in a narrow sense and to primarily focus on the second pillar, mostly military-related issues (e.g. Gänzle et al. 2007; Gärtner 2003; Hyde-Price 2004; Kaldor et al. 2007; Kirchner 2006; Longhurst et al. 2004; Matlary 2008; Moschini 2008; Salmon 2005). There has been a recent move by some scholars (e.g. Dannreuther 2006; Diez et al. 2006; Gänzle 2007; Keukeleire 2004; Lavenex 2004;) which argues that the European Union's policy of conflict prevention, for example, demands more than just effective military capabilities. Moritz Weiss (2008: 2) makes it clear, that "given the characteristics of today's security problems, military capabilities do not represent a conditio sine qua non for effective security policy". In his article, he argues that the resolution of contemporary conflicts demands more tools than military capabilities alone. This article does not question the argument made by Weiss; instead, it builds on it by emphasizing that regional conflicts are only one of the security concerns in the contemporary debate. Moreover, these 'broader' concerns are increasingly triggered by more fundamental challenges, such as climate change; for example, a significant volume of contemporary security studies literature includes at least one chapter on the environment (e.g. Dalby 2008; Dyer 2000; Dannreuther 2007; Homer-Dixon 2004; Hough 2004; Kay 2006; McNeill 2003; Terriff et al. 2005). This begs the question, 'if the meaning of the security concept in Europe has broadened significantly during the last

The author would like to thank Sarah Leonard and Christian Kaunert for their exceptional help with this project, as well as Vasilis Margaras and other participants of the UACES Student Forum 9th Annual Conference at the University of Kent in April 2008 for their valuable feedback. The author would also like to thank the Editor of JCER and anonymous referees for their insightful comments. For the linguistic help the author would like to thank Alex Mackenzie. 
few decades, why is it not fully reflected in the literature on the EU as a security actor?' Although there are many authors investigating the EU's actorness in the area of climate change (e.g. Bretherton et al. 2006; Groenleer et al. 2007; Lacasta et al. 2002; McCormick 2001; Schreurs et al. 2007; Vogler 2005), they conduct their analyses in the context of European foreign or environmental policy, not applying their findings to rethink the EU's role as a comprehensive security actor.

This seems to suggest that the literature on EU security, by adopting a rather narrow, military-oriented approach to the concept of security, focusing on the CFSP or the ESDP, appears to adhere to a 'rational' or 'realist' approach to how security is understood. This article suggests that part of the problem is that the literature on the EU as a security actor or European foreign policy (EFP) often lacks a clear conceptualization of security. If a publication on the EU security strategy or attitudes does not fully explain what the author means by security, then it can be difficult to properly follow his or her analysis of the empirical material. The reader may ask why certain problems were included as security issues, while others were omitted.

This article is divided into four main sections. In the first section, a general overview of how the concept of security has evolved over the last few decades is provided. From being 'underdeveloped', focusing on the nuclear rivalry, security became a 'highly contested' concept with issues such as climate change, health and migration being considered as having consequences for international and national security. The second section expands on the theoretical overview and suggests that more coherence between the literature on the EU as a security actor and the literature on the security studies is achievable. One possible way forward is to adopt a more balanced approach between security which is theoretically-oriented and that which is empiricallygrounded. To help with this, one possible way of defining a security problem is suggested. These first two theoretical sections are then followed by an empirical section which discusses part of the current EU security agenda. The aim of this third section is to show that it is not only the literature on contemporary security studies which approaches security in a more inclusive way, but also the EU itself; for example it has recently adopted a 'security lens' to examine problems such as climate change. Finally, the fourth section shows that even though security has adopted a broader and deeper conceptualisation, both in theory and in practice, the literature on the EU as a security actor is still dominated by the narrow and military-oriented approach. The aim of this juxtaposition is to show the nature of the discrepancy between the two different approaches to security within the literature.

\section{Broadening and deepening security}

The purpose of this section is to briefly examine the process of redefinition of the concept of security. Firstly, it will be shown how the concept of security evolved during the Cold War to become much broader and encompass many problems which are not military in nature (Buzan 1983; Ullman 1983). Secondly, the article will look at the postCold War developments in security. It is important to briefly examine the expansion of the security concept, because, as will be shown in the final section of the article, the literature on the EU as a security actor does not entirely reflect the development of the security concept as found in post-Cold War security studies literature. This discrepancy is problematic because it affects the conclusions of scholars working on the security actorness of the European Union, and, as such, leads to the perception that the EU is less of a security actor than it actually is. There are a wide variety of opportunities in which the EU can play an important role in international security. They range from assisting Russia in the destruction of the world's largest chemical weapons stockpile to the EU's first naval operation against pirates off the coast of Somalia. They also include a broad spectrum of initiatives on issues such as climate change or poverty in developing countries, where often a "conflict trap is part of the poverty trap" (UNDP 
2005: 157). A more holistic approach to the EU as a security actor is required as it would reflect developments within the security studies literature and allow a better understanding of the role of the EU as a provider of security.

In the early decades of the post-WWII era, especially after the development of nuclear capability by key states around the world, the meaning of security was hardly questioned and "the political questions about the nature of security were subsumed by strategic or technical questions relating to nuclear weapons" (Fierke 2007: 15). Security was primarily about preserving autonomy of the state and freedom of decision-making, by the means such as armed forces, diplomacy and intelligence, but also economic leverage and cultural superiority (Sheehan 2005: 6).

Barry Buzan $(1983 ; 1991)$ is one of the scholars who challenged this situation at the beginning of the 1980s, when he introduced five sectors of security (military, political, economic, societal and environmental), in which an interstate military conflict was still a primary, but not the only security threat. Similarly, the state was still the main referent object to be secured, but the levels of individuals and international system were also recognized. The work of Barry Buzan was ground-breaking to the extent that "acknowledging the merits of a 'broad concept of security' and of Buzan's authority on the subject became a reflex of security scholars" (McSweeney 1999: 53).

Buzan (1991; 2007: 107) acknowledged that "military threats occupy the traditional heart of international security concerns" because they basically affect all the functions of the state. But there are also other kinds of problems. Political threats, for example, can include the overthrow of the government/regime or weakening the political structure of the state so it is more vulnerable to, for example, coup d'état. Societal threats are strongly interlinked with the political ones and they may be displayed in the form of an attack on the nation's identity. Buzan suggested, that when a local culture and traditions are not highly developed, contact with a more dominant culture, religion or language can be disrupting and therefore raise the feeling of insecurity. Economic threats to security are the most problematic or controversial ones because the insecurity of actors operating within an economy is an inherent part of the system, and this insecurity is necessary for the market to work efficiently. However, there are a number of problems which may have security consequences, for instance when the economy of the state is declining, its importance in relation to other states can also decline. Ecological threats were also acknowledged, because they "can damage the physical base of the state" (Buzan 2007: 117). Throughout history, the natural environment has always been taken as a background to human activity, but due to human activity it has become an issue of increasing importance. Some scholars that have adopted this broadened conceptualisation of security have argued it is essential for governments to recognise these multiple threats; for example, Richard Ullman (1983) went as far as arguing that by concentrating mainly on the military aspects of security, the US government ignored other dangers and therefore undermined the national security of the American state.

The most rapid expansion of the concept of security came with the end of the Cold War. In the 1990s it became possible to distinguish at least three "broad churches" (Mutimer 2007) within which scholars have attempted to broaden and deepen the concept of security. They all aimed at challenging the traditional, materialist and military-oriented view on security. This article will now briefly outline some of the main characteristics of these three attempts.

The first effort to open the discussion on security was undertaken in 1994 at the York University in Toronto, where a conference entitled, Strategies in Conflict: Critical Approaches to Security Studies, was held. This conference resulted in the publication of the book, Critical Security Studies: Concepts and Cases (Krause et al. 1997) which outlined some direct challenges to the traditional assumptions of security. According to the authors, apart from the state, the referent objects of security can take on a human 
dimension and, as such, include individuals and communities which have their own security concerns, as well as those problems which relate to humanity as a whole.

The second of these broad churches on security is commonly referred to as the Copenhagen School. This school became widely recognized with the book Security: $A$ new framework for analysis (1998) by Barry Buzan, Ole Wæver and Jaap de Wilde and can be considered the second major attempt to reassess security in the post-Cold War era. The Copenhagen School developed its arguments around the two key concepts: Buzan's five sectors of security and Wæver's ideas about securitization. The sectors, significantly broadening the agenda for security studies, as already mentioned, include military, political, economic, societal and environmental security. The concept of securitization has been highly influential in security studies since its development and it can be of great use in studying how the rhetoric of policy-makers changes when a problem, once considered a public policy or scientific issue, begins to be treated as a matter of security.

The third 'broad church' in security studies was developed in Aberystwyth and is sometimes referred to as the Welsh School. It is first and foremost anti-Realist; Ken Booth (2005), a prominent representative of the Welsh School, accuses Realism of being not realistic. For Booth, "what is real in social universe is created by the theory conceiving it" (Booth 2005: 10). This approach assertively separates itself from both social constructivism for being focused on the state and from the Copenhagen School for being focused on state/society (Smith 2005). Instead, the researcher should look at the "individual men's and women's experiences of threat, as well as other well-being aspirations (Alker 2005: 195). Emancipation of the individual is a goal of studying security. Wyn Jones (2005: 216) suggests that even though there are differences within the Welsh School about how to approach emancipation, "some concept of emancipation is a necessary element of any form of analysis that attempts to problematize and criticize the status quo".

These developments in security studies are not fully reflected in the literature on the EU as a security actor. As will be shown in this article, the tendency among EU scholars focusing on security is to narrow down the perspective and investigate mostly the EU's performance in addressing the so called 'high politics' challenges (e.g. Gänzle et al. 2007; Gärtner 2003; Hyde-Price 2004; Kirchner 2006; Longhurst et al. 2004; Salmon 2005), while neglecting other activities, such as, the EU's agenda setting in climate change. Interestingly, even the chapter called 'The Comprehensive Security Concept of the European Union' (Moschini 2008) in the book Globalization and Environmental Challenges concentrates mainly on EU's military capabilities and, ironically, does not mention the Union's role in environmental security at all. Publications that discuss the EU's security actorness in a holistic manner constitute a modest minority (e.g. Charillon 2005; Hintermeier 2008; Sjursen 2004). It is suggested in the empirical section that climate change can have numerous implications for international security and stability. For example, it threatens the existence of the Pacific islands (UN ESCAP 2000), which represents a non-traditional security problem and also it accelerates the rivalry over the Arctic's resources, which symbolizes more traditional, geopolitical territorial games (Kefferpütz et al. 2008; Schepp 2009).

\section{A balanced approach to security}

The purpose of this part of the article is to see how a more balanced approach between the empirically-grounded and theoretically-oriented security can contribute to increased cohesion between the literature on contemporary security studies and the literature on the EU as a security actor. This section also discusses one possible way of defining security and refers in this respect to the work of Paul D. Williams (2008) and to the UN Secretary-General's High-level Panel on Threats, Challenges and Change (2004). 
The concept of security is highly contested. There is no agreement on what kinds of problems should be considered security issues and what the most appropriate referent object of security is: the human being, groups of people or the state. The fact that there are so many different definitions and understandings of security (Collins 2007: 3; Baylis 2008: 229) is a result of the rapid proliferation of the literature in the field of security studies after the Cold War, as it was outlined in the previous section. Barry Buzan (1991: 7) went as far as suggesting that security is an "essentially contested concept", which means that it generates unsolvable debates about its meaning and application. Not all agree with this assessment. Ken Booth (2007), for example, counter-argues that the reason why we are tempted to see security as 'essentially contested' is because it was 'uncontested' for such a long time. For the author, the core meaning of security is uncontested, but it becomes contested when applied to world politics with all "the layers of meaning that derive from different political theories" (Booth 2007: 100).

Regardless of the degree to which an agreement on the concept of security is possible, this article makes an argument that every analysis must be structured around the problems which people already struggle with, or are likely to face in the near future. Roland Dannreuther (2007), for example, strongly favours the empirical model which focuses less on 'abstract theorizing', and more on empirical research. Barry Buzan (2000: 2) expressed the following concern: "Some people think that there is too much theorising about security and not enough concern with events in the real world". The very powerful point for the more empirically-grounded approach to security was expressed by Kofi Annan (2005: 63), when he was still the General Secretary of the UN. It deserves to be quoted in length:

\begin{abstract}
Ask a New York investment banker who walks past Ground Zero every day on her way to work what today's biggest threat is. Then ask an illiterate 12-year-old orphan in Malawi who lost his parents to AIDS. You will get two very different answers. Invite an Indonesian fisherman mourning the loss of his entire family and the destruction of his village from the recent, devastating tsunami to tell you what he fears most. Then ask a villager in Darfur, stalked by murderous militias and fearful of bombing raids. Their answers, too, are likely to diverge.
\end{abstract}

It is always problematic to present one definition of anything in social sciences, but keeping in mind the balance between the theoretical and the empirical approach to security, this article follows Paul Williams (2008: 5) and suggests the following understanding of security: "alleviation of threats to cherished values; especially those which, if left unchecked, threaten the survival of a particular referent object in the near future". There are few compelling characteristics of this approach to the security concept. Firstly, it talks about values, which have to be respected in order for the referent object to feel secure. Evans et al. (1998: 490), similarly, define security as an "absence of threats to scarce values". This understanding implies that the threat does not have to be existential. Ken Booth (2007: 102) explains that survival is about "continuing to exist", whereas security means freedom from "life-determining threats, and therefore space to make choices" (Booth 2007: 102). In other words, a referent object can survive but may not feel secure, like the 12-year old orphan from Kofi Anan's quotation, who lost both parents to AIDS.

Secondly, Williams' understanding of security does not predetermine any particular referent object. An analyst has to make a choice and the number of possible referent objects is growing rather than narrowing down. Throughout the Cold War, security was associated with the 'national security' of a state. Barry Buzan introduced individual, societal and international levels of analysis, but still preferred to focus on the state, being a "central to the whole concept of security" (1991: 57). As already indicated, the Welsh School is primarily interested with security of individuals, as is the whole concept of Human Security (Hampson 2008). Societal groups became a referent object in its own right with the book Identity, Migration and the New Security Agenda in Europe (1993) by Ole Wæver, Barry Buzan, Morten Kelstrup and Pierre Lemaitre. Finally, according to Paul D. Williams (2008), the Earth emerges as a new referent object because the whole of humankind is dependent on the natural environment in which it exists. 
Thirdly, the threat does not have to occur immediately, but may emerge in the near future. As Micheal Sheenan (2005: 59) explains, "the danger may not be immediate, but it is apparent and is likely to manifest itself within a foreseeable time scale". Climate change constitutes a good example of a challenge which does not have to threaten people instantly, but if unchecked, may have a very profound impact on the conditions of living, by, for example, severely limiting access to water (Smith et al. 2007).

One comprehensive overview of dangers to 'cherished values' was prepared by the UN Secretary-General's High-level Panel on Threats, Challenges and Change (2004), identifying six clusters of threats:

a) Economic and social threats, including poverty, infectious diseases and environmental degradation - these so called 'soft' security issues are considered to be more lethal for developing countries than traditional, military conflicts (Dodds et al. 2005).

b) Inter-State conflict - with a number of unresolved disputes in regions such as South Asia.

c) Internal conflict, including civil war, genocide and other large-scale atrocities - with prominent examples of Rwanda and Kosovo.

d) Nuclear, radiological, chemical and biological weapons - potentially the greatest threats to human existence.

e) Terrorism - with trans-national, armed networks such as Al-Qaeda and the danger of attacks resulting in mass casualties.

f) Transnational organized crime - with drug trafficking as the single most important source of criminals' income.

These threats and challenges represent a holistic approach to security going beyond, but not neglecting, a traditional problem of military conflicts. All of them constitute a profound danger to 'cherished values' of individuals and societies and some of them are truly existential. The following section provides the evidence that not only the contemporary security studies literature, but also the EU itself has started to broaden its understanding of security in its policy-making practice.

\section{The security policy of the European Union}

In this section the article examines securitisation of climate change as a threat multiplier', by looking at major EU documents such as the European Security Strategy (European Council 2003). It is suggested that in recent years the EU has increasingly presented climate change as a problem which already has, or will have consequences for international security and stability and not just for the natural environment.

After the Cold War, it has not only been the EU which has been developing a more holistic approach to security. The UN Security Council in 2007, just like in previous years, was preoccupied with military-related problems such as terrorism and proliferation of weapons of mass destruction. Yet, among these issues, the organization, for the first time, addressed the problem of climate change. The discussion proved to be controversial. For example, Italian delegate Vittorio Craxi, pointed out that "climate change is an unequivocal global threat" (UN Security Council 2007), whereas China insisted that the "Council was not the proper forum for a debate on climate change" (UN Security Council 2007). Regardless of disagreements, the precedent was set. NATO, created as a defence pact, expanded its competences throughout 1990s. Member states agreed in the Organisation's Strategic Concept (NATO 1991) that "Risks to Allied security are less likely to result from calculated aggression against the territory of the Allies, but rather from the adverse consequences of instabilities that may arise from the serious economic, social and political difficulties". In 1998 NATO established the Euro-Atlantic Response Coordination Centre, with the main 
function "to coordinate the response of NATO and partner countries to natural or manmade disasters within the Euro-Atlantic area" (NATO 1998).

The European Union has a long history of attempting to develop its capabilities in the field of defence and security. The turning points in this regard were the development of the European Political Cooperation (EPC) in the 1970s, the Treaty of Maastricht (1991), the Treaty of Amsterdam (1996), the Saint Malo summit (1998) and development of the ESDP (Salmon et al. 2003; Smith 2002). These, however, relate mostly to the EU's second-pillar, intergovernmental cooperation and the military-related aspects of security, whilst the purpose of this section is to investigate a broadening of the security concept within the organization's practice.

EU concerns relating to the non-military dimension of security were most prominently expressed in the 2003 European Security Strategy (ESS). The EU acknowledged in this document that security is a very complex problem. For example, it recognized that "AIDS is now one of the most devastating pandemics in human history and contributes to the breakdown of societies" (European Council 2003: 2). The document also recognised that problems such as hunger and various diseases severely undermine economic growth in developing countries, which very often leads to violent conflicts. Global warming is mentioned in the context of increasing competition for natural resources, such as water, but the document does not pay a lot of attention to it.

The revised version of the ESS, officially called the Report on the Implementation of the European Security Strategy (European Council 2008), reshuffles priorities for EU security. Climate change has been 'elevated' and figures on the list of 'Global Challenges and Key Threats' along with proliferation of weapons of mass destruction (WMD), terrorism, organised crime and energy security. The document explains that climate change "has taken on a new urgency" (European Council 2008: 5) and that "Natural disasters, environmental degradation and competition for resources exacerbate conflict, especially in situations of poverty and population growth" (European Council 2008: 5). The document also refers to the report Climate change and International Security, prepared jointly by the High Representative and the European Commission (2008) and submitted for consideration to the EU's member state leaders attending the European Council Summit in Brussels in March 2008.

This report constitutes an important step for the EU in developing a more holistic approach to security. It identifies a number of threats resulting from the average increase of global temperatures, and also focuses on specific regions which are most vulnerable to climate change. For example, the report points out that the rising sea level can seriously affect those living close to the seas and oceans, along with infrastructure like oil refineries. Especially endangered will be inhabitants of small islands, which could be entirely flooded by rising sea water. The document also refers to the Arctic region, where melting ice caps uncovering large resources of hydrocarbon can trigger new geopolitical rivalry.

In November 2008 the European Commission published a separate document about the Arctic region, in which it suggested that this area will be "increasingly at risk from the combined effects of climate change and human activity" (European Commission 2008: 2). The melting ice caps of the Arctic represent new opportunities, such as new transport routes, but also new challenges, which can be divided into two categories. There is, on the one hand, a more traditional danger of major powers' race over natural resources and, on the other hand, a more human-oriented threat to indigenous people and local populations. In September 2008 Russian ministers held an unprecedented meeting of the National Security Council at the far northern Franz Josef Land. After the meeting, Council secretary Nikolay Patrushev said that "the Arctic must become Russia's main strategic resource base" (Russia to boost its presents in Arctic 2008). The potential danger of militarisation of the Arctic region reveals more 'hard-policy' results of climate change. The EU attempts to position itself as an actor in addressing these 
challenges by, for example, engaging in dialogue with Norway and Russia over the exploration of hydrocarbon resources (European Commission 2008).

The process of the EU explicitly acknowledging the security implications of climate change is relatively new. However, if security is about the 'alleviation of threats to cherished values', there are many instances of EU actions in the past which were concerned with environmental security. For example, following the accident at the chemical plant in Seveso, Italy, the European Community adopted the Council Directive 82/501/EEC on the major-accident hazards of certain industrial activities (Council of the European Communities 1982). This Directive was significantly updated and expanded in 1996 by the Council Directive 96/82/EC on the control of major-accident hazards (Council of the European Union 1996). Since 1999 this so called Seveso Directive II is obligatory for industry and public authorities of the Member States.

\section{Contrasting two strands of the literature}

The aim of this section is to demonstrate the nature of the problem with the literature on the security actorness of the European Union. As mentioned earlier, security is understood as 'alleviation of threats to cherished values; especially those which, if left unchecked, threaten the survival of a particular referent object in the near future'. This approach to security breaks with the Cold War exclusive focus on national survival and strategic defence. The previous section demonstrated that the EU has been developing as a security actor in a broader sense for many years now, which is nothing unusual, taking into account the similar practice of other international organisations. This process has not yet been fully reflected in the literature on the EU as a security actor, which tends to structure its arguments around the institutional configurations of the EU (e.g. Gänzle et al. 2007; Howorth 2007; Kaldor et al. 2007; Matlary 2008). It is not suggested that EU's own institutional arrangements should not be investigated and better understood, rather on the contrary (e.g. Rieker 2007 on political/administrative capabilities of CFSP/ESDP or Duke et al. 2006 on administrative governance in the CFSP). But it is suggested that if a publication aims at investigating the EU as a security actor, then the author should align the analysis with his or her understanding of security and not just with the EU's institutional structure. As mentioned before, this article suggests that a more holistic conceptualisation of security can help to better understand the nature of the EU's security actorness. Two strands of the literature are relevant for analysis in the context of the EU's security actorness (Rieker 2007). Firstly, this section examines the publications narrowing down their focus to the EU's security actorness. Secondly, the category of the literature on the broader notion of European foreign policy is analysed.

\section{The EU as a security actor}

The review of the literature on the EU as a security actor reveals that there is a tendency to approach security more narrowly than it is treated in the publications on contemporary security studies; this fact creates discrepancy between these two kinds of literature. One source of this divergence is that authors do not explicitly provide their own understanding of security, but at the same time they assume a more traditional approach, focused on military capabilities.

For example, Jolyon Howorth (2007) starts his volume Security and Defence Policy in the European Union with the chapter entitled 'Introduction: A New Security Actor on the World Stage'. However, even though the book is about defence and security in the EU, the whole analysis is limited only to the ESDP. Obviously, there is nothing wrong about choosing ESDP as a subject of a detailed analysis. Yet what remains problematic is why the author chooses to focus only on one institution of the European security apparatus? More broadly: what does it mean for the EU to be a security actor? What is 
security in the 21 st century? If these questions were answered, the rest of the analysis would be easier to follow.

Kerry Longhurst and Marcin Zaborowski (2004: 390) elaborate on the divisions within the EU over the war in Iraq, but conclude that the EU can eventually become a security actor because it "has the institutions and some military capabilities". Although no definition is provided, the military-oriented approach can be recognised. Trevor Salmon (2005), in his article about EU security, is interested in the impact of the Iraq campaign on the European (lack of) cooperation. Although not providing a definition of security, Salmon draws very far reaching conclusions about the EU performance on the global stage: "Apart from economic instruments, most other instruments are embryonic. The EU has failed to play the global actor card" (Salmon 2005: 378).

The second source of discrepancy between the two kinds of literature analysed in this article, is that some authors adopt an explicitly traditional approach to security. Adrian Hyde-Price (2004: 335), for example, explains that broadening the notion of security is harmful to the process of studying the concept, because the discipline loses its rigour and therefore it "ends up being everything and nothing". Hyde-Price's point has its merit; it certainly was easier to study security policy when there was an almost universal agreement what the concept meant in the Cold War context. However, the security agenda has significantly broadened in the last few decades. Not reflecting this fact, when studying the EU, must lead to the conclusion that the EU is less of a security actor than it is when the broadened security agenda is accepted.

Peter Sherman and Matthew Sussex (2004: 23) do not recognise the EU as a security actor for the following reason: "Despite forces of globalization and the growth of transnational terrorism, politics still takes place within territorial boundaries of the nation state". James Wyllie (1997) in his volume European Security in the New Political Environment also does not recognise the EU as an actor. Instead, the author underlines that "the international system remains a competitive and basically anarchic system of states" (Wyllie 1997: 9).

The third suggested source of divergence between the literature on contemporary security studies and the EU literature is that publications on the EU as a security actor do acknowledge that the concept of security has broadened, but this is not fully reflected in the empirical analysis of the EU's performance on the international scene.

For example, Emil J. Kirchner (2006) in his article The Challenge of European Union Security Governance acknowledges that security can include different dimensions such as ecology or society. Yet his whole analysis is about the EU's military and civilian missions. Stefan Gänzle et al. (2007: 4) make it clear in their volume that the end of the Cold War "diminished - perhaps even eliminated - the territorial and military defence focus of European security in the past". Yet the authors do not reflect this fact in the empirical parts of their book, devoted mainly to the European Neighbourhood Policy and relations with the strategic partners: the US and Russia. Steve Marsh et al. (2005) in The International Relations of the European Union also acknowledge the role of the end of the Cold War in broadening the concept of security: "This conceptual and indeterminate broadening of security had potentially profound implications for the EC [European Community] as an international security actor" (Marsh et al. 2005: 19). Surprisingly, however, authors do not address in detail any of the 'broad security' issues in the context of the EU's performance on the world scene.

The reader could expect a broader understanding of security in the literature focusing on the concept of human security, which Janne H. Matlary (2008: 135) defines as the "agenda where the point of reference is the individual person and his or her right to personal security". However, in her article Much ado about little: the EU and human security, Matlary (2008) chose not to look beyond the CFSP/ESDP cooperation and therefore her conclusion is inevitable: "the EU may benefit from calling all its security 
policy 'human security', but if rhetoric promises more than policy can deliver, the ethical implications are grave" (Matlary 2008: 143). If the author looked not only at the second-pillar EU policy, but also at the preventive efforts such as the EU's leading role in the UN negotiations on climate change, the conclusion could be more optimistic. Mary Kaldor et al. (2007: 273) in the article Human Security: a new strategic narrative for Europe stated that "severe threats to human security range from genocide and slavery to natural disasters such as hurricanes or floods to massive violations of the right to food, health and housing". This approach looks promising. However, when it comes to analysing EU's policy, the authors focus purely on ESDP operations. Limiting the analysis of EU security policy to the second-pillar cooperation omits other EU activities, which can have a profound impact on human security. The aforementioned EU's role in the UN negotiations on climate change is one of them.

\section{European foreign policy}

The review of the literature on the EFP (or the EU as an international/global actor) suggests that this literature also tends to adopt a narrow understanding of security, by limiting its scope of analysis regarding the EU's security actorness to the Union's second-pillar activities in the framework of the CFSP/ESDP (e.g. Cafruny et al. 1998; Hill et al. 2005; Smith 2003; White 2001). Often this literature provides an analysis of other EU external policy areas such as the environment, but this does not help to better understand the comprehensive nature of EU security actorness. This fact contributes to the discrepancy with the literature on contemporary security studies and increasingly also with the EU's own approach to problems such as climate change. This article suggests that a broader approach to security, not limited to military-related threats and responses, can help to better understand the comprehensive nature of the EU as a security actor.

The problem is not that authors adopt an explicitly narrow approach to security, but rather that they often do not explain how they understand security at all, limiting their analysis of the EU's security actorness to what the EU has been labelling its security apparatus, namely the CFSP/ESDP. Perhaps the recent developments, where the EU itself begins to acknowledge the security implications of challenges such as climate change, will encourage the EU scholars to change their approach as well. This article suggests that authors writing about the EFP should make an effort to define what they mean by security. That would serve as a justification and explanation for the choices they make with regard to what part of the EU's activity they analyse. Moreover, if those scholars fully acknowledged that the security agenda has broadened in the last few decades, that would help to improve our understanding of the comprehensive nature of the EU's security actorness.

The volume by Charlotte Bretherton et al. (2006) is one of the most influential books on EU foreign policy. The authors acknowledge that "internal and external aspects of security are indissolubly linked and thus involve not only the ESDP and the Community but also Pillar III (...)" (Bretherton et al. 2006: 212). But what is the EU's role as a security actor? According to the authors, the role is threefold: a) providing security and stability for the wider Europe, b) counter-terrorism and countering proliferation of WMD, c) external crisis management (Bretherton et al. 2006: 191). The authors do not acknowledge that the environment, development and humanitarian aid policies also constitute a dimension of the EU's comprehensive security policy. This article suggests that these policies play an important role in development of the $\mathrm{EU}$ as a comprehensive security actor.

Fraser Cameron's (2007) volume is ambiguous because the author does not define what he considers to be a security issue and therefore does not elaborate on the concept of security. For example, his section on environmental policy follows the one on air transport and even though Cameron (2007: 13) states that "the EU has also 
become an important actor in global environmental policy", he does not explain whether he means security actorness or broader political actorness only. Karen Smith (2003: 2) examines "what the EU actually does in international relations". Yet, none of the problems discussed in her book are approached as security challenges. Even the policy of conflict prevention is explicitly named by Smith as an EU foreign policy objective and not a security one. Being more specific about the security dimension of the EFP would help to better understand EU security actorness.

The volume edited by Christopher Hill et al. (2005) is a very comprehensive attempt to reassess the EFP, including two chapters on security. Firstly, Jolyon Howorth examines the evolution of the second pillar, focusing mainly on military cooperation. In another chapter Wyn Rees concentrates on issues such as terrorism and migration, usually associated with the third pillar - the EU's area of freedom, security and justice. This arrangement nicely reflects the institutional configuration of the EU, but it does not help to better understand the comprehensive nature of the EU as a security actor.

Another, more recent, systematic analysis of the EFP is the book by Stephan Keukeleire et al. (2008). The authors examine the EU's external activity across all three pillars. In contrast to most of the other contributions on the EFP, this volume introduces a brief explanation of how the idea of security has broadened, explaining concepts such as global, societal and human security. However, when discussing the actual EU activity, the authors go only half the way through, acknowledging security implications of issues such as health and demography, but not identifying the security dimension of, for example, environmental change. This fact reflects how fluid the concept of security is. However, a systematic examination of EU policy in the context of global, societal and human security would make an important contribution to understand the security actorness of the EU. Moreover, it would bring the EFP literature much closer to the literature on contemporary security studies, shrinking the existing discrepancy between these two.

\section{Conclusion}

This article discussed how the concept of security became highly problematised and contested in the literature on contemporary security studies. Even though there is no agreement on a single definition of security, the vast majority of the 'security' scholars in Europe depart from a realist framework. In the empirical part it was shown that the broad understanding of security is not only a matter of an academic analysis, but also is increasingly reflected in the political practice of the major international organizations. The purpose of these theoretical and empirical examinations was to contrast them with a more traditionalist approach of the literature on the EU as a security actor and the EFP. It is argued in this article that the literature on the European Union as a security actor too often adopts a narrow, military-orientated notion of security. It was emphasised that approaching the problem of the EU's security actorness from a traditional perspective can lead to the conclusion that the EU is an underdeveloped security actor, considering its relatively weak military capabilities. A broader understanding of security, on the other hand, can help to better our understanding of the comprehensive nature of the EU's security actorness.

It is probable that the gap between the broad understanding of security in the literature specifically on that subject and the narrower approach in the publications focused on the EU will shrink in the near future. One of the reasons for this is that, as demonstrated in the empirical section, the European Union itself is redefining its understanding of security. It will be more intuitive for authors to acknowledge security implications of problems not traditionally associated with security, once both the literature and the policy of the EU approach them as such. 


\section{References}

Alker, H. (2005). 'Emancipation in the Critical Security Studies Project', in K. Booth (ed.), Critical Security Studies and World Politics. Boulder: Lynne Rienner.

Annan, K. (2005). "'In Larger Freedom": Decision Time at the UN', Foreign Affairs, 84 (3), pp. 63-74.

Baylis, J. (2008). 'International and Global Security', in J. Baylis, S. Smith and P. Owens (eds), The Globalization of World Politics. New York: Oxford University Press.

Booth, K. (2005). 'Critical Explorations', in K. Booth (ed.), Critical Security Studies and World Politics. Boulder: Lynne Rienner.

Booth, K. (2007). Theory of World Security. Cambridge: Cambridge University Press.

Bretherton, C. and Vogler, J. (2006). The European Union as a Global Actor. London: Routledge.

Buzan, B. (1983). People, States and Fear. Brighton: Wheatsheaf.

Buzan, B. (1991). People, States and Fear, 2nd edition. London: Wheatsheaf.

Buzan, B. (2000). 'Change and Insecurity Reconsidered', in S. Croft and T. Terriff (eds), Critical Reflections on Security and Change. London: Frank Cass.

Buzan, B. (2007). People, States and Fear: An agenda for international security studies in the post-Cold War era. Colchester: ECPR Press.

Buzan, B., Wæver, O. and De Wilde, J. (1998). Security: A New Framework for Analysis. Boulder, Colo.: Lynne Rienner Pub.

Cafruny, A.W. and Peters, P. (1998). The Union and the World: The Political Economy of a Common European Foreign Policy. Dordrecht: Martinus Nijhoff Publishers.

Cameron, F. (2007). An Introduction to European Foreign Policy. London: Routledge.

Charillon, F. (2005). 'The EU as a security regime', European Foreign Affairs Review, 10 (4), pp. 517-533.

Collins, A. (2007). 'Introduction: What is Security Studies?', in A. Collins (ed.), Contemporary Security Studies. Oxford: Oxford University Press.

Council of the European Communities (1982). Council Directive 82/501/EEC on the majoraccident hazards of certain industrial activities. Brussels: Council of the European Communities.

Council of the European Union (1996). Council Directive 96/82/EC on the control of majoraccident hazards. Brussels: Council of the European Union.

Dalby, S. (2008). 'Environmental Change', in P.D. Williams (ed.), Security Studies: An Introduction. London: Routledge.

Dannreuther, R. (2006). 'Developing the Alternative to Enlargement: The European Neighbourhood Policy', European Foreign Affairs Review, 11 (2), pp. 183-201.

Dannreuther, R. (2007). International Security: the Contemporary Agenda. Cambridge: Polity.

Diez, T., Stetter, S. and Albert, M. (2006). 'The European Union and Border Conflicts: The Transformative Power of Integration', International Organization, 60 (3), pp. 563593.

Dodds, F. and Pippard, T. (2005). Human and Environmental Security: An Agenda for Change. London: Earthscan.

Duke, S. and Vanhoonacker, S. (2006). 'Administrative Governance in the CFSP: Development and Practice', European Foreign Affairs Review, 11 (2), pp. 163-182.

Dyer, H. (2000). 'Environmental Security: The New Agenda', in C. Jones and C. KennedyPipe (eds), International Security in a Global Age: Securing the Twenty-first Century. London: Frank Cass.

European Commission (2008). Communication from the European Commission to the European Parliament and the Council: The European Union and the Arctic Region. Brussels: European Commission.

European Council (2003). European Security Strategy. Brussels: European Council.

European Council (2008). Report on the Implementation of the European Security Strategy - Providing Security in a Changing World. Brussels: European Council.

Evans, G. and Newnham, J. (1998). The Penguin Dictionary of International Relations. London: Penguin Books.

Fierke, K.M. (2007). Critical Approaches to International Security. Cambridge: Polity. 
Gänzle, S. (2007). 'The European Neighbourhood Policy: a Strategy for Security in Europe?', in S. Gänzle and A. Sens (eds), The Changing Politics of European security: Europe alone? Basingstoke: Palgrave Macmillan.

Gänzle, S. and Sens, A. (2007). The Changing Politics of European security: Europe alone? Basingstoke: Palgrave Macmillan.

Gärtner, H. (2003). 'European Security: The End of Territorial Defence', Brown Journal of World Affairs, 9 (2), pp. 135-147.

Groenleer, M. and Van Schaik, L. (2007). 'United We Stand? The European Union's International Actorness in the Cases of the International Criminal Court and the Kyoto Protocol', Journal of Common Market Studies, 45 (5), pp. 969-998.

Hampson, F.O. (2008). 'Human Security' in P.D. Williams (ed.), Security Studies: An Introduction. London: Routledge.

High Representative and European Commission (2008). Climate Change and International Security. Brussels: High Representative and European Commission.

Hintermeier, S. (2008). 'Reconceptualization of External Security in the European Union', in H.G. Brauch, C. Mesjasz, J. Grin, P. Dunay, Ú.O. Spring, B. Chourou, P. KameriMbote, P. H. Liotta and N.C. Behera (eds), Globalization and Environmental Challenges: Reconceptualizing Security in the 21st Century. Berlin: Springer.

Hill, C. and Smith, M. (eds), (2005). International Relations and the European Union. Oxford: Oxford University Press.

Homer-Dixon, T.F. (2004). 'Environmental Scarcities and Violent Conflict: Evidence from Cases', in M. Brown, O. Coté, S. Lynn-Jones and S. Miller (eds), New Global Dangers: Changing Dimensions of International Security. Cambridge: The MIT Press.

Hough, P. (2004). Understanding Global Security. London: Routledge.

Howorth, J. (2007). Security and Defence Policy in the European Union. New York: Palgrave Macmillan.

Hyde-Price, A. (2004). 'European Security, Strategic Culture, and the Use of Force', European Security, 13 (4), pp. 323-343.

Kaldor, M., Martin, M. and Selchow, S. (2007). 'Human security: a new strategic narrative for Europe', International Affairs, 83 (2), pp. 273-288.

Kay, S. (2006). Global Security in the Twenty-first Century. Lanham: Rowman \& Littlefield Publishers.

Kefferpütz, R. and Bochkarev, D. (2008). Expanding the EU's Institutional Capacities in the Arctic Region: Policy Briefing and Key Recommendations. Brussels: Heinrich Böll Stiftung.

Keukeleire, S. (2004). 'EU Structural Foreign Policy and Structural Conflict Prevention', in V. Kronenberger and J. Wouters (eds), The European Union and Conflict Prevention. The Hague: Asser.

Keukeleire, S. and MacNaughtan, J. (2008). The Foreign Policy of the European Union. New York: Palgrave Macmillan.

Kirchner, E. (2006). 'The challenge of European Union Security Governance', Journal of Common Market Studies, 44 (5), pp. 947-968.

K. Krause and M. Williams (eds), (1997). Critical Security Studies: Concepts and Cases. London: UCL Press.

Lacasta, N., Dessai, S. and Powroslo E. (2002). 'Consensus among many voices: articulating the European Union's position on climate change', Golden Gate University Law Review, 32, pp. 351-414.

Lavenex, S. (2004). 'EU External Governance in "wider Europe"', Journal of European Public Policy, 11 (4), pp. 680-700.

Longhurst, K. and Zaborowski, M. (2004). 'The Future of European Security', European Security, 13 (4), pp. 381-391.

Marsh, S. and Mackenstein H. (2005). The International Relations of the European Union. Harlow: Pearson Education.

Matlary, J.H. (2008). 'Much ado about little: the EU and human security', International Affairs, 84 (1), pp. 131-143.

McCormick, J. (2001). Environmental Policy in the European Union. Hampshire: Palgrave. 
McNeill, J. (2003). 'Environmental Change and Security', in M. Brown (ed.), Grave New World: Security Challenges in the $21^{\text {st }}$ Century. Washington D.C.: Georgetown University Press.

McSweeney, B. (1999). Security, Identity and Interests: A Sociology of International Relations. Cambridge: Cambridge University Press.

Moschini, R.M. (2008). 'The Comprehensive Security Concept of the European Union', in H.G. Brauch, C. Mesjasz, J. Grin, P. Dunay, Ú.O. Spring, B. Chourou, P. KameriMbote, P.H. Liotta and N.C. Behera (eds), Globalization and Environmental Challenges: Reconceptualizing Security in the 21st Century. Berlin: Springer.

Mutimer, D. (2007). 'Critical Security Studies: A Schismatic History', in A. Collins (ed.), Contemporary Security Studies. Oxford: Oxford University Press.

NATO (1991). The Alliance's New Strategic Concept. Available at: http://www.nato.int/docu/comm/49-95/c911107a.htm, last accessed 5 March 2009.

NATO (1998). The Euro-Atlantic Disaster Response Coordination Centre. Available at: http://www.nato.int/issues/eadrcc/index.html, last accessed 5 March 2009.

Rieker, P. (2007). The EU as a Security Actor: The development of political and administrative capabilities. Oslo: Norwegian Institute of International Affairs.

Russia to boost its presents in Arctic (2008). Available at: http://www.barentsobserver.com/index.php?id=4510159, last accessed 5 March 2009.

Salmon, T. (2005). 'The European Security and Defence Policy: Built on Rocks or Sand?', European Foreign Affairs Review, 10 (3), pp. 359-380.

Salmon, T. and Shephard, A. (2003). Toward a European Army: A Military power in the Making. Boulder: Lynne Rienner Publishers.

Schepp, M. and Traufetter, G. (2009). 'Russia Unveils Aggressive Arctic Plans', Spiegel Online. Available at:

http://www.spiegel.de/international/world/0,1518,604338,00.html,

last accessed 5 March 2009.

Schreurs M. and Tiberghien Y. (2007). 'Multi-Level Reinforcement: Explaining European Union Leadership in Climate Change Mitigation', Global Environmental Politics, 7 (4), pp. 19-46.

Shearman, P. and Sussex, M. (2004). European Security after 9/11. Aldershot: Ashgate.

Sheehan, M. (2005). International Security: An Analytical Survey. London: Lynne Rienner Publishers.

Sjursen, H. (2004). 'Security and Defence', in W. Carlsnaes, H. Sjursen and B. White (eds), Contemporary European Foreign Policy. London: Sage.

Smith, D. and Vivekananda, J. (2007). A Climate of Conflict: The links between climate change, peace and war. London: International Alert.

Smith, H. (2002). European Union Foreign Policy: What it Is and What it Does. London: Pluto Press.

Smith, K. (2003). European Union Foreign Policy in a Changing World. Oxford: Polity.

Smith, T. (2005). 'The Contested Concept of Security', in K. Booth (ed.), Critical Security Studies and World Politics. Boulder: Lynne Rienner.

Terriff, T., Croft, S., James L. and Morgan P. (1999). Security Studies Today. Cambridge: Polity.

Ullman, R. (1983). 'Redefining Security', International Security, 8 (1), pp. 129-153.

UN Development Programme (UNDP) (2005), Human Development Report 2005. New York: UN

UN Economic and Social Commission for Asia and the Pacific (ESCAP) (2000). Climate Change and the Pacific Islands. Available at: http://www.unescap.org/mced2000/pacific/background/climate.htm, last accessed 6 March 2009.

UN Secretary-General's High-level Panel on Threats, Challenges, and Change (2004). A more secure world: Our Shared Responsibility. New York: UN.

UN Security Council (2007). 5663 ${ }^{\text {rd }}$ Meeting S/PV.5663. New York: Department of Public Information. 
Vogler, J. (2005). 'The European contribution to global environmental governance', International Affairs, 81 (4), pp. 835-850.

Wæver, O., Buzan, B. and Kelstrup, M. (1993). Identity, Migration and the New Security Agenda in Europe. Boulder, CO: Westview Press.

Weiss, M. (2008). 'The "Political Economy of Conflicts": A Window of Opportunity for CFSP?', Journal of Contemporary European Research, 4 (1), pp. 1-17.

White, B. (2001). Understanding European Foreign Policy. Basingstoke: Palgrave.

Williams, P.D. (2008). 'Security Studies: An Introduction', in P.D. Williams (ed.), Security Studies: An Introduction. London: Routledge.

Wyllie, J. (1997). European security in the new political environment. Harlow: Longman.

Wyn Jones, R. (2005). 'On Emancipation: Necessity, Capacity, and Concrete Utopias', in K. Booth (ed.), Critical Security Studies and World Politics. Boulder: Lynne Rienner. 